\title{
Potentiality of Water Resources in the Kirala Kele Partial- Nature-Based Wetland of Southern Sri Lanka
}

\author{
S. L. J. Fernando \\ Department of Geography, \\ University of Ruhuna, Matara, Sri Lanka
}

\begin{abstract}
The semi nature based wetlands are areas characterized by a high percentage of artificial environments, which are saturated with water, either permanently or seasonally, it determines the nature of soil development and the types of animals and plant communities in the soil. Sri Lanka can earn more benefits such as being able to provide direct financial benefits for conservation and management of wetlands, financial benefits and empowerment for local people, and build environmental and cultural awareness of how to sustain the resources of wetlands. This paper explores the potential water resources of the partial-nature-based wetland at Kirala Kele for the long-term development. The evaluation process of the water resources was based on six main criteria, including surface water, rainfall, relative humidity, evapotranspiration, terrain and ground water of the area. Those factors were generated from the land use/land cover map and field observation with GPS points. The spatial and temporal changes in the wetland area from 1983 to 2011 were analyzed using satellite remote sensing and GIS. There has been a positive correlation and significant relationship between relative humidity (RH) and rainfall (RF) in the Kirala Kele wetland area for thirty four years.
\end{abstract}

Key words: Water resources, rainfall, relative humidity, partial-nature-based wetland

\section{INTRODUCTION}

Wetlands are one of the most productive ecosystems for many biological species, including humans. They provide a source of food and building materials for human kind and serve very important natural functions such as flood control and filter the surface water into the ground. Further, these habitats are home to a wide range of important aquatic species. Even though wetlands are inundated by surface or ground water, it cannot be defined only by the components of hydrological sources and hydric soil condition. Frequent presence of ground water close to the surface and multi species of vegetations is a preliminary requirement for the long term sustainability in the wetlands.

Adopted for our common future the sustainable use of wetlands means that human use of wetlands, which may yield the greatest continuous benefit to present generations while maintaining the potentials to meet the needs and aspiration of future generations (Slootweg \& Schooten, 2001). Thus, the wetland resources should be used to fulfill economic and social needs (Socio economic Development) while conserving the biodiversity and ecological processes of the ecosystem at the same time. The wetland soils that are permanently or periodically saturated with water can be developed while the wetland related components such as water, vegetation, soil and land uses are compared to the surrounding areas (Kolka \& Thompson, 2006).

Water is the determining factor to resilience of wetland ecosystems and wetland defined in terms of hydrological regime. The spatial and temporal patterns of water saturation of the 
wetlands tend to provide a valuable feeding source into the wetlands. Without certain hydrological criteria and hydric soil, an area of land cannot be defined as a wetland. Therefore, the frequent presence of ground water close to the surface under normal condition is a preliminary requirement for the long term existence of the wetlands. Wetland hydrology involves the spatial and temporal distribution, circulation and physiochemical characteristics of surface and subsurface water and its catchment over time and space (Richardson et al., 2001). The manual of the National Food Security Act (2007) points out some criteria of hydrology in the wetland as, the area is inundated or saturated to the surface for at least $5 \%$ of the growing season in most years; The area is inundated for at least 7 consecutive days during the growing seasons and soil may be considered saturated of the water table is within $0.5 \mathrm{ft}$ to $01 \mathrm{ft}$ (NRCS, 2007).

Natural wetlands are decreasing due to poor water resources, reclamation, pollution, over exploitation, sedimentation and various degradation activities of human intervention likewise, while artificial wetlands are spreading owing to the abundance of low lying areas with poor resources.

\section{STUDY AREA}

Kirala Kele is a coastal wetland located near Matara town area in the Southern province of Sri Lanka. Kirala Kele wetland area does not have nature based characteristics totally. It has evolved as a back swamp behind the Nilwala River in the right bank of the basin and then it had changed as a partial nature based wetland as a consequence of inappropriate changes in the physical properties of water and soil in the area. The Kirala Kele wetland located between $5^{\circ}, 58^{\prime} 38^{\prime \prime} \mathrm{N}-5^{\circ}, 59^{\prime} 35^{\prime \prime} \mathrm{N}$ and $80^{\circ}, 31^{\prime}, 27^{\prime \prime} \mathrm{E}-80^{\circ}, 34^{\prime}, 25^{\prime \prime} \mathrm{E}$ has a geographical area of 1800 hectares. It is situated between Matara - Akuressa main road and Matara - Hakmana main road in the west and east of the wetland, and it is three (3) km away from the Matara city in the south of Sri Lanka (See Figure 1.1). A total of about 4880 hectares (12390 acres) of land, including low lying wetland which occupies 300 hectares (750 acres) is identified as Kirala Kele sub watershed. Out of 2000 hectares or 5000 acres were possessed under the flood protection scheme (Nihal, 1996).

Figure 1.1 - Geographical location of Kirala Kele wetland in Sri Lanka

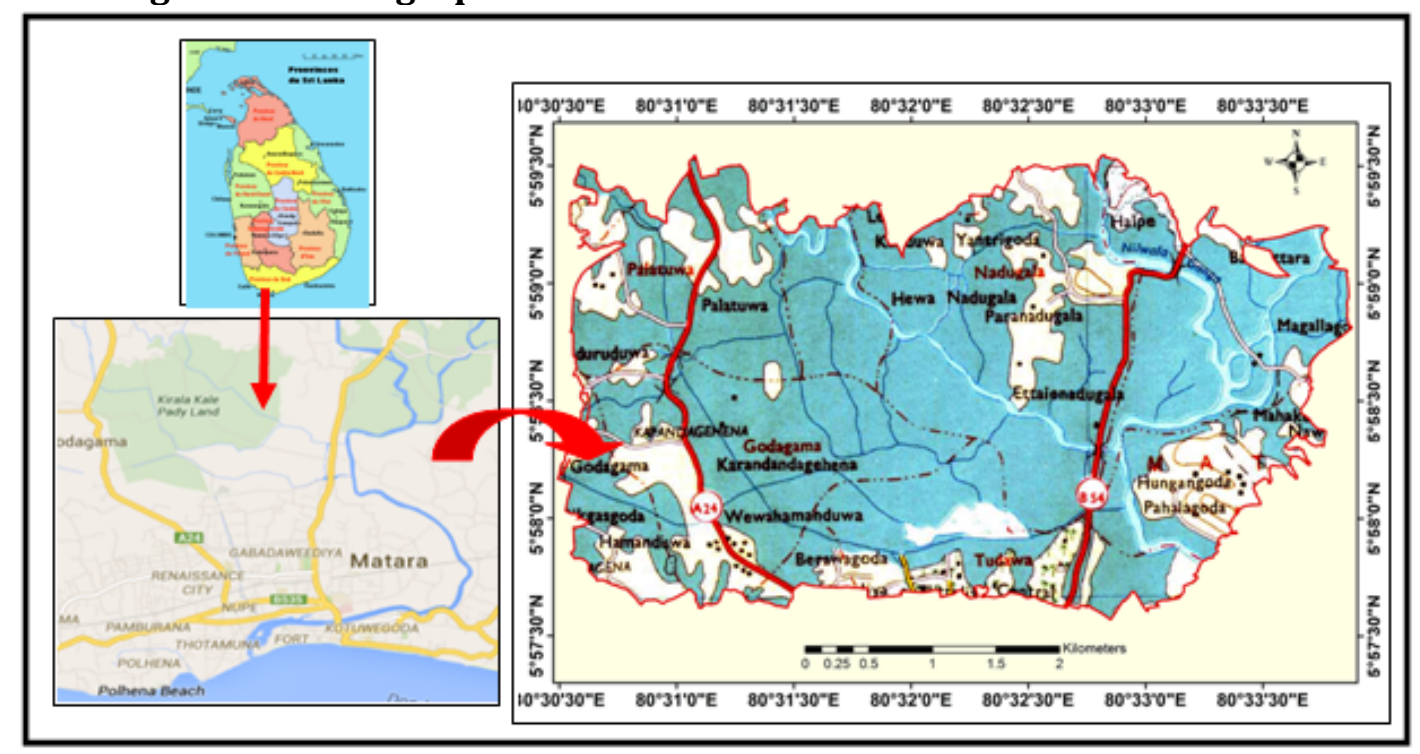

An area of more than 310 hectares of the wetland has been declared as a protected area of the wetland. It had been promoted as "Conserved Kirala Kele Abaya Buumiya" under Sri Lanka's picturesque sites programmed in 2003 by a special gazette notification. 


\section{Data sources}

\section{MATERIALS AND METHODOLOGY}

This study has used a mixed method (Qualitative and quantitative) research approach based on a survey research strategy and ancillary data. Based on the characteristics pertaining to the design of the research, the study applied a survey research using field work and findings from pre-studies for the data collection in order to accomplish the main objective of the research.

The selected attributes of rivers, streams, canals and water bodies from the shape files of land use, land cover in 2011 and exported to Area of Interest (AOI) data from the Survey Department and River discharge data were collected from the Irrigation Department of Matara, Sri Lanka under this category. The meteorological data used in this study provided by the Meteorological Department. The data were compressed with rainfall (1980-2013), temperature and Relative Humidity (RH) of the study area in the Excel format. The salinity data were gathered for the study from the Faculty of Agriculture and Department of Geography, University of Ruhuna, Matara, Sri Lanka. In addition, the data used a literature survey to prove the hydrological sources into the wetland (Fernando \& Suranganee, 2009; Aberathna, 1995; Delpachithra, 1996; Weerasingha et al., 1996; Nissanka, 1996; Nihal, 1996 and Premalal, 2012). The data analysis procedure employed with two stages of both Arc GIS 10.0 window and Arc GIS 10.0 with the extension of Analytic Hierarchy Process (AHP).

\section{Method}

The water resource factor was generated from the land use/land cover map and field observation with GPS points. Having converted to the raster layer of the water resources map, it was reclassified into four categories for the AHP analysis. This was carried out by the Euclidean Distance Analysis on the spatial analysis window. In this study, the highly suitable ranges of the water resources were determined by the distance from water bodies (Figure 1.4). In this study, factors associated with water resources comprised of rivers, canals, tanks and small ponds in the area. AOI of rivers and canals were extracted from the hydro-line shape file with regard to the area generated by the Survey Department of Sri Lanka. Small water bodies and water logged areas were inserted into the water resources map using 'Selected attributes tool' on the attribute table of the land use/ land cover (LU/LC) layer. A classified map with four categories ('high water area', 'marginal water area' 'moderate water area' and 'low water area') was built depending on the water availability of the area on the 'Spatial analysis' tool box using 'Euclidian distance' tool. Furthermore, rainfall and discharge data of the area were analyzed by the descriptive statistical method of the SPSS version 18.0 and Microsoft Excel window. Pearson Correlation Coefficient analysis was used to assess the relationship between relative humidity (RH) and rainfall (RF) in the Kirala Kele wetland.

\section{RESULTS AND DISCUSSION}

Wetland water budget is an important factor in the hydrologic process in the wetland. It depends on the inflow and outflow of water from a wetland. Furthermore, six types of field indicators of hydrology of the wetland have been identified by the proceed, namely, observation of inundation, observation of soil saturation, watermarks, drift lines, sediment deposits and drainage pattern in wetlands (Vepraskas, Craft, \& Richardson, 2002). These field indicators are occurring based on the water budget in the wetland.

Inflow source surface water enters the wetland by normal stream flow, flood water, overland flow, ground water discharge and tides (Carter, 1994). It may be permanent, temporary or seasonally fed into the wetland. Kandanmodara is an only water outfall into the Kirala Kele wetland from the main river Nilwala. As the perennial river flows through the wetland area, some ground water discharge and water from the broadly circulated canal system can infiltrate 
water into the wetland. Upper and middle portion of the watershed boundary of the Nilwala river system is wide and lower parts narrow down. The hydrology of the lower part of the river basin (Flood plain including Kirala Kele wetland) is mainly controlled by the main river, the river branches and the small water fountains surrounding the wetland. The main river includes five sub watersheds namely, Kotapola Ganga, Urubokka Ganga, Hulandawa Ganga, Siyambalagoda Ganga, Digili Oya and Kirama Ara. In between Deniyaya, Beralapanathara and Morawaka the river flows through less hilly terrain from where Hulandawa Ganga and Digili Oya join the main river as seen in Figure 1.2 (Perera, 1996).

Figure 1.2 - Hydrological sources in the Kirala Kele wetland area.

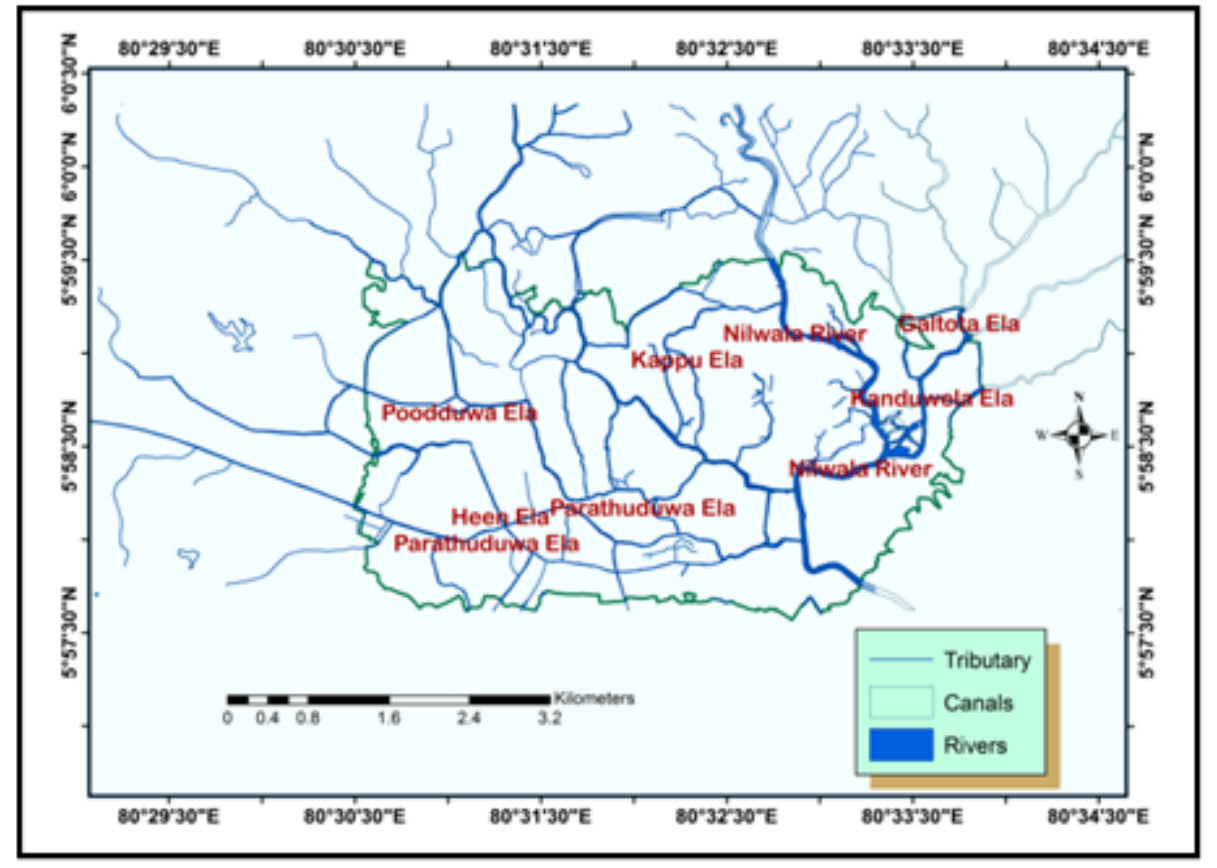

Source: Survey Department, 2005

Rainfall is a subcomponent of precipitation and has a dramatic effect on the water budget of the wetland. Estimated rainfall of the upper catchment area of Nilwala River varies from 2500 $\mathrm{mm}$ to $4000 \mathrm{~mm}$ and average annual rainfall is recorded at $3386.83 \mathrm{~mm}$ (Pushpakumara et al, 2012). Annual average rainfall of the lower basin of Nilwala River varies from $1250 \mathrm{~mm}$ to $2000 \mathrm{~mm}$ and average annual rainfall of the study area has recorded $1307.25 \mathrm{~mm}$ within the 34 years between 1980 and 2013. Monthly rainfall statistics in Kakanadura meteorological station (Nearest station to Kirala Kele wetland) for the period of 1980 to 2013 indicated the highest total monthly rainfall in 2007, i.e $2162.7 \mathrm{~mm}$ (average $180.23 \mathrm{~mm}$ ) and the lowest in 1989, i.e $665.7 \mathrm{~mm}$ (average 55.48mm). Furthermore, lower catchment receives heavy rainfall from May to September each year during the southwest monsoon period (Figure 1.3). 
Figure 1.3 - Annual average rainfall in Kirala Kele (1980-2012)

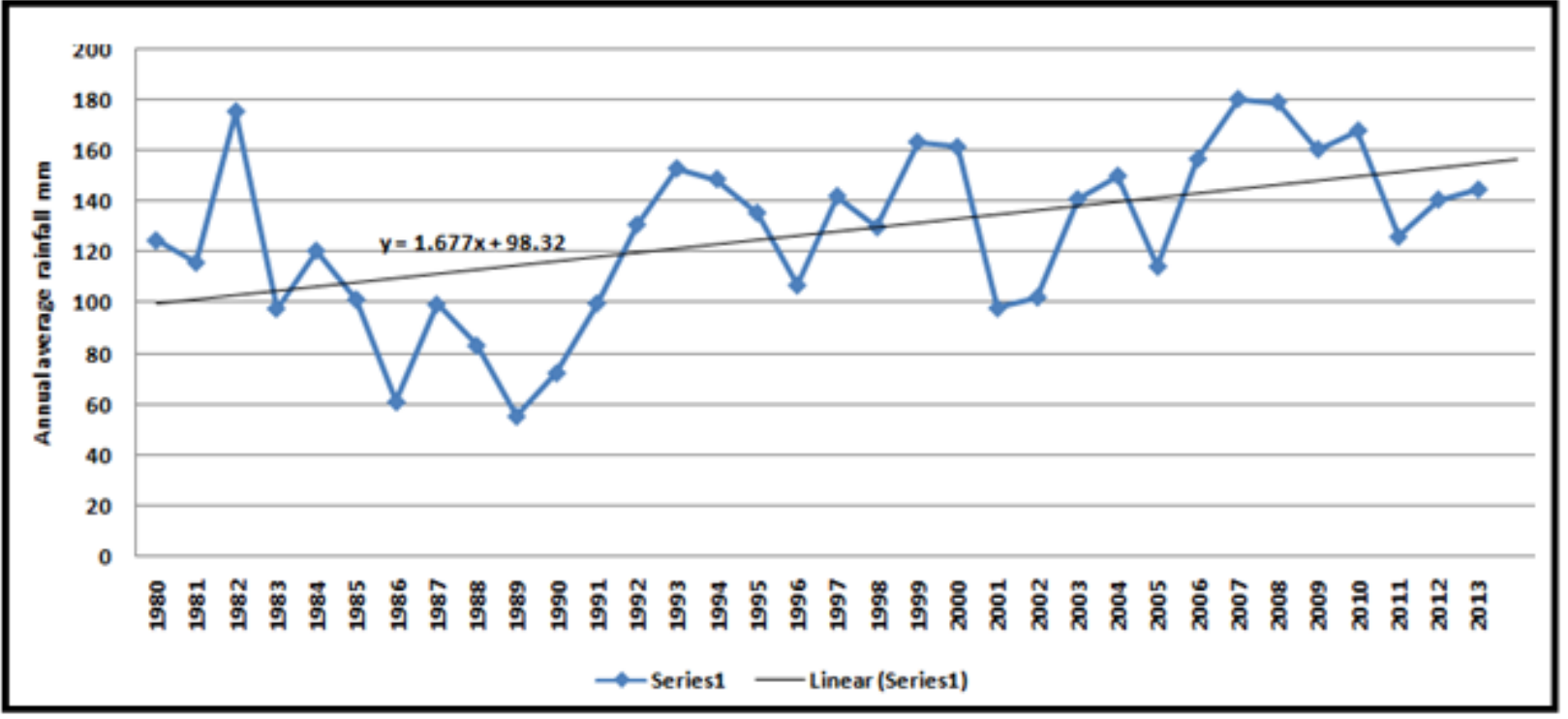

Source: Meteorological Department, Colombo, Sri Lanka

A recent trend in rainfall in Sri Lanka is the heavy and high intensity of rainfall, it is high in the western slope (some portion above the study area) and runoff increases due to the high intensities (Premalal, 2012). Therefore, the high intensity of rainfall would be affected by prevailing to a strong hydrological feedback and accumulating sediment load into the wetland for the interrelated natural ecosystem process.

The Nilwala River watershed is dispersed in the wet zone where the mean annual rainfall is $1300-3300 \mathrm{~mm}$ in the upper basin and $1900 \mathrm{~mm}$ annual rainfall process in the lower basin. The evaporation is $1550 \mathrm{~mm}$. The lower basin, including the Kirala Kele area protects the wet ecosystem condition, due to high rainfall over the evaporation. Even the Kirala Kele wetland has a scatter pattern of vegetation which is observed as a wide range of bushes. Excluding above plots, a lot of surface lands are covered with water bodies and Eleaocharis dulcis. This eco-status could be contributed to the preservation of water resources on the surface and be in charge of evapotranspiration in the Kirala Kele wetland. The persevered water bodies are seen at the surface of the wetland area as small ponds (Figure 1.4). 
Figure 1.4 - Classified classes of the water bodies in the Kirala Kele wetland.

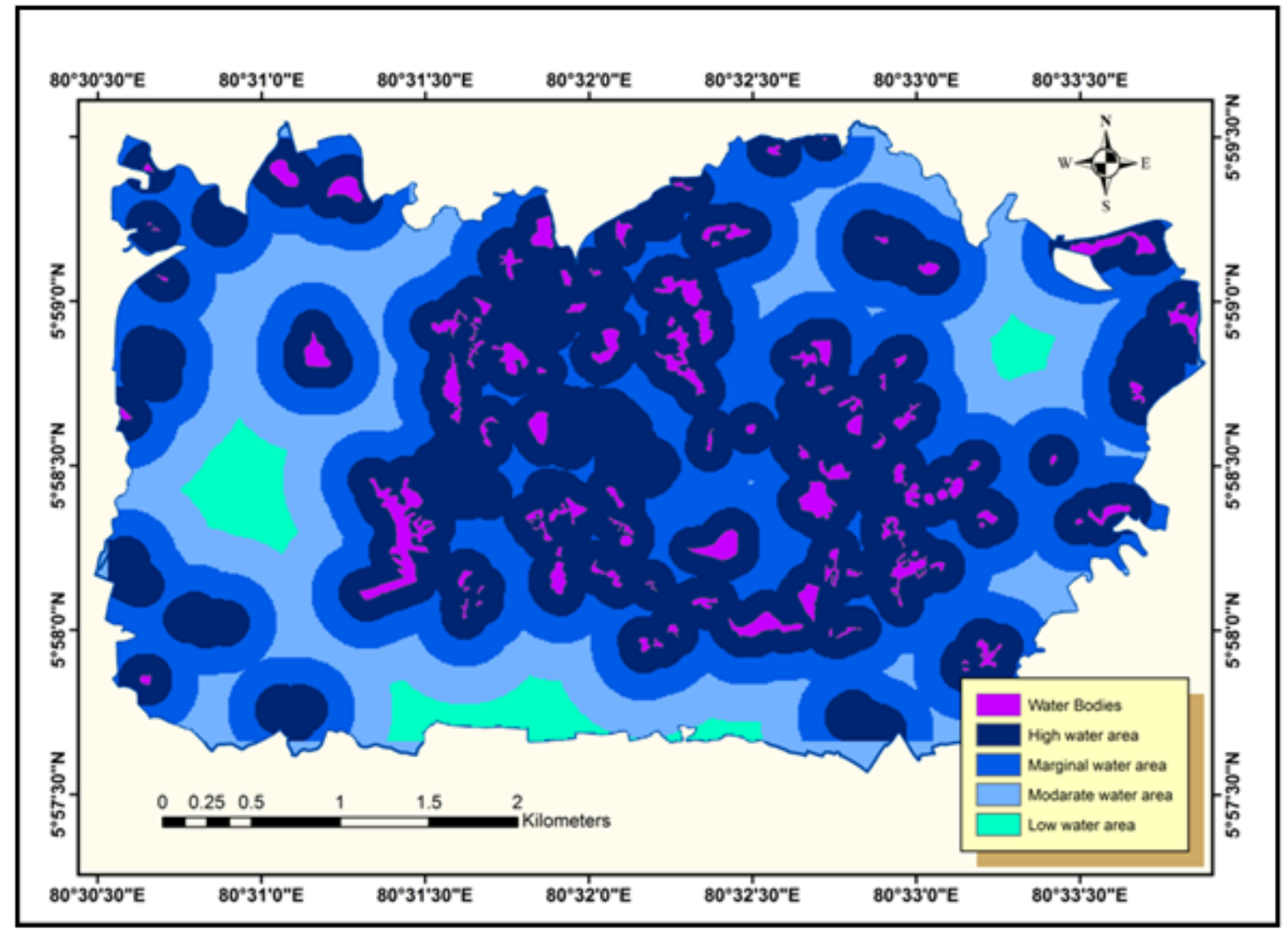

Source: Field observation with GPS points, 2015

Evaporation and transpiration is an impact factor for determining the water budget in the wetland. Solar radiation and angle of the waves, vegetation type, surface vegetation cover, wind speed, turbulence, relative humidity, soil moisture and geomorphologic desperate are some depending factors to evapo-transpiration of the wetland (Bidlake, 2000; Carter, 1996).

Evaporation, relative humidity and rainfall of the water budget in the wetland have a great relationship to the survival of inflow and outflow of the system. Relative humidity is the percentage of water vapor air can hold at a particular air temperature (Umoh, Akpan, \& Jacob, 2013 ). Relative humidity has its significance in weather control surrounding environment as cold or warm. When cold, relative humidity is low and warmer condition it is high. When the temperature is high and relative humidity is low, tend to rapid evaporation become dry soil effects of the temporary change weather condition of the wetland (Umoh, Akpan \& Jacob, 2013). It also has a greater influence on water temperature, water level and salinity (Sanches et al., 2004).

However, the percentage of monthly average relative humidity data from the Kirala Kele wetland area has $>80 \%$ every month in a year. High percentage of relative humidity can exist the moisture content of the system for the natural equilibrium of this wetland. Minimum and maximum average $\mathrm{RH}$ records high percentage between $76 \%$ - 90\% within last 34 years of this wetland area. In part, this has been a result of the high rainfall and low evaporation of the wetland. Figure 1.5 depicts the relationship between average monthly rainfall and average monthly relative humidity of the study area. 
Figure 1.5 - The relationship between monthly average rainfall and relative humidity in the study area (1983-2013)

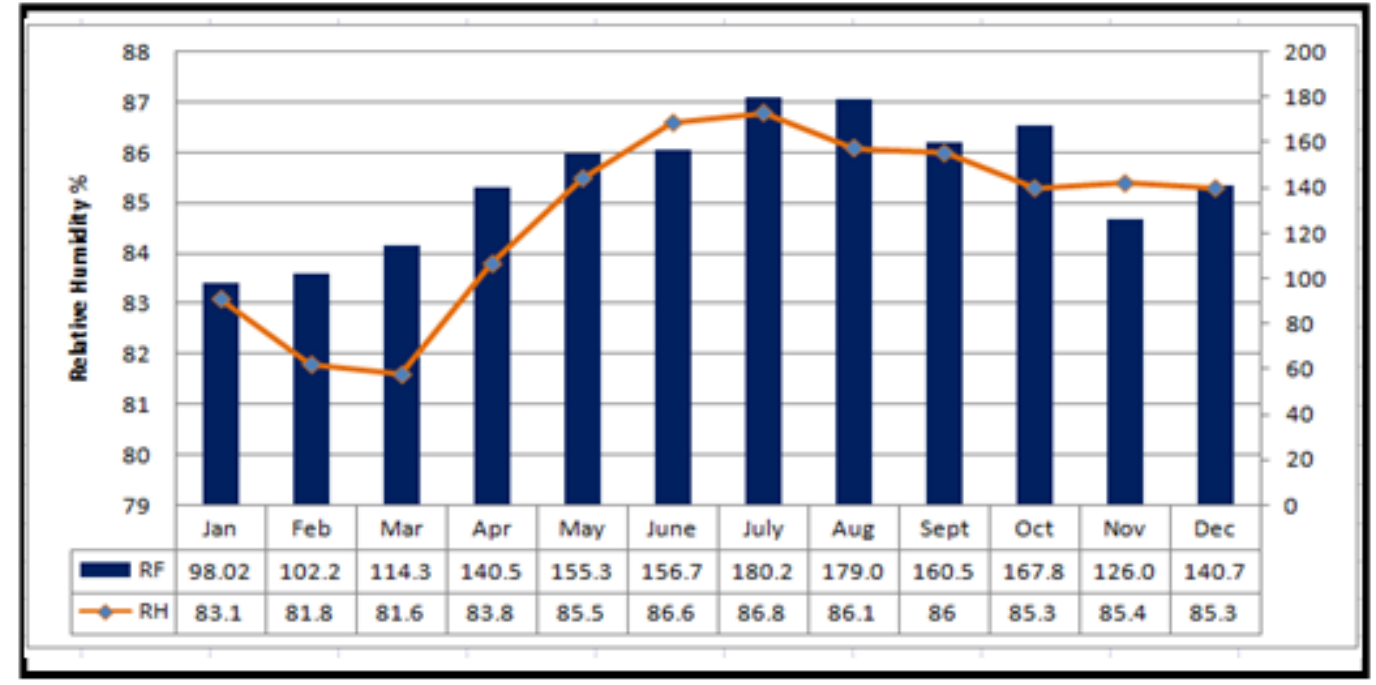

Relative humidity (RH) in Sri Lanka typically ranges from $60 \%-90 \%$ and is generally higher in the southwest and mountainous areas, although it is also affected by seasonal patterns and rainfall (RF) (Meteorological Department, 2014). As shown in Figure 1.5, the pattern of the two components was noticeably similar during the southwest monsoon period, though there were some fluctuations between months in a year. Both variables have become more similar upward trend with higher standard rates through the months up to August. The percentage of RH has increased quite sharply since May at $85.5 \%$ to $86.8 \%$ in July while the average monthly rainfall ranged $153.3 \mathrm{~mm}$ in May to $180.2 \mathrm{~mm}$ on July. Moreover, both variables behaved the same way during the two inter-monsoon periods. When the first monsoon period (March to April) the rainfall was $140.5 \mathrm{~mm}$ and $\mathrm{RH}$ was $83.8 \%$ and during the second monsoon the monthly average RH and RF have become high as $167.8 \mathrm{~mm}$ and $85.3 \%$ respectively.

Pearson Correlation Coefficient was computed to assess the relationship between relative humidity (RH) and rainfall (RF) in the Kirala Kele wetland area during the thirty four years. There is a positive correlation and significant relationship between $\mathrm{RH}$ and $\mathrm{RF}, \mathrm{r}=0.764, \mathrm{n}=34$, $\mathrm{p}=.000$. The scatter plot and the regression line, summarizes the results (See Figure 1.6).

Figure 1.6 - Relationship between relative humidity and rainfall

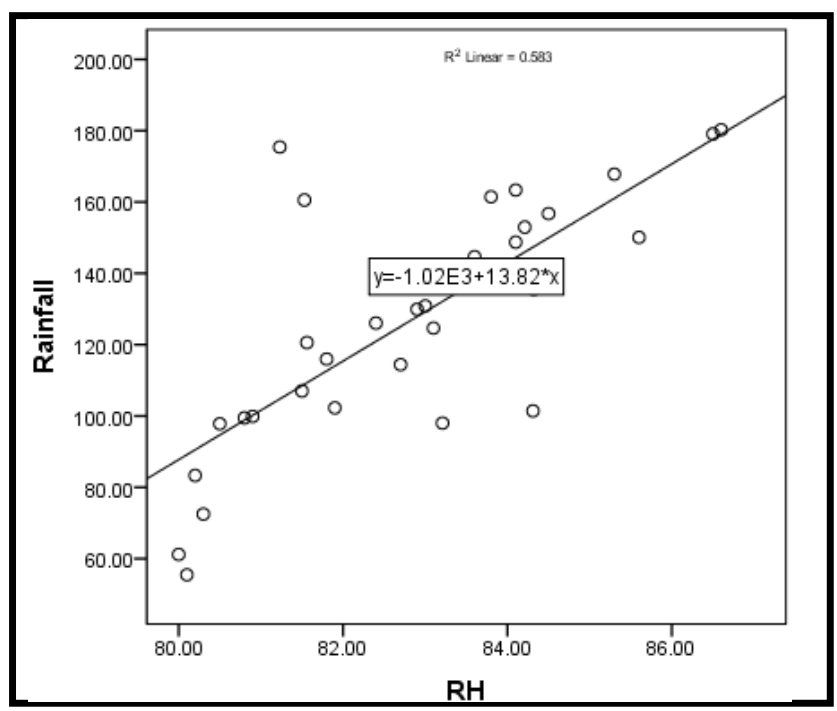


There is a strong positive correlation between RH and RF in this wetland area. The increases in $\mathrm{RH}$ were significantly related to increases in RF in the Kirala Kele wetland area. It is evident that, two major components of the water budget in the wetland have more potential to conserve the wetland.

\section{CONCLUSION}

The water resources of the wetland are based on the inflow and the outflow of the water budget. The Monsoon and convectional rain percolate as the main inflow source of this wetland all over the year and the overall trend of the quantity slightly increased during 1980-2012. The high percentage of Relative Humidity $(\mathrm{RH})$ can hold the particular moisture content of the wetland. Minimum and maximum RH was recorded between 76\%-90\% within last 34 years. Therefore, both variables enhanced the inflow of the water table of this wetland. The river discharge and flood peak periods, are subject to the crucial time for the accumulation of sediments. Most vulnerable period to floods in this area prevails in the inter-monsoon period and also lead to inundation in the monsoon period.

\section{References}

Aberathna, M. D. C. (1996). Land use and land management practices of the Nilwala Basin. Review of Engineering Technology, 2(Open University, Sri Lanka), 70-81.

Bidlake, W. R. (2000). Evapotranspiration from a bulrush-dominated wetland in the klamath basin, oregon1. JAWRA Journal of the American Water Resources Association, 36(6), 1309-1320.

Carter, V. (1994). Wetland hydrology, water quality, and associated functions. National Water Summary on Wetland Resources, 35-48.

Delpachitre.U. (1996). Nilwala Ganga Flood Protection Scheme Paper presented at the Rehabilitation of the Nilwala Basin, Faculty of Engineering Tcehnology, The Open University of Sri Lanka.

Fernando, G. W. A. R. a. S., R.K.N. (2009). Development of Acid Sulphate Soils in Nilwala Flood Protection Area, Matara, Sri Lanka. Journal of Geological Society of Sri Lanka, 13(2009), 71-82.

Kolka, R. K., \& Thompson, J. A. (2006). Wetland geomorphology, soils, and formative processes. Ecology of Freshwater and Estuarine Wetlands, 7-42.

Nihal, F. (1996). A Holistic Approach for Land and Water Management in Nilwala Basin Paper presented at the Rehabilitation of the Nilwala Basin, Faculty of Engineering Tcehnology, The Open University of Sri Lanka.

Nissanka, N. A. U. (1996). Problem created by Nilwala Ganga Flood Protection Scheme and suggested solution. Review of Engineering Technology, 2(Open University, Sri Lanka), 15-27.

NRCS. (2007). National Food Security Act Manual (NFSAM) (Vol. 514). Natural Resources Conservation Service, 6013 Lakeside Blvd, Indianapolis, IN 46278 Natural Resources Conservation Service

Premalal, K. H. M. S. (2012). Variability of rainfall in Sri Lanka in the context of climate change. Journal of the Sri Lanka Association of Geographers, Vol 1 (No 1), 72-81

Perera, S. S. M. W. W., A. (1996). Iregation of Remote Sensing and GIS for land use /land cover mapping in Nilwala basin. Paper presented at the Rehabilitation of the Nilwala Basin, Faculty of Engineering Technology, The Open University of Sri Lanka.

Pushpakumara, P. K. P., Y.T.; Saman, S.L.; Elisebeth, M.L. (2012, June). Soil erosion of the upper catchment of Nilwala. Paper presented at the National Conference of Environmental Issues, Colombo.

Richardson, J., Arndt, J., \& Montgomery, J. (2001). Hydrology of wetland and related soils. Wetland soils-Genesis, hydrology, landscapes, and classification, 35-84.

Sánchez-Carrillo, S., Angeler, D. G., Sánchez-Andrés, R., Alvarez-Cobelas, M., \& Garatuza-Payán, J. (2004). Evapotranspiration in semi-arid wetlands: relationships between inundation and the macrophyte-cover: openwater ratio. Advances in Water Resources, 27(6), 643-655.

Slootweg, R., Vanclay, F., \& van Schooten, M. (2001). Function evaluation as a framework for the integration of social and environmental impact assessment. Impact Assessment and Project Appraisal, 19(1), 19-28.

Umoh, A. A., Akpan, A. O., \& Jacob, B. B. (2013). Rainfall and relative humidity occurrence patterns in Uyo Metropolis, Akwa Ibom state, South-South Nigeria. IOSRJEN, 3, 27-31. 
Vepraskas, M. J., Craft, C. B., \& Richardson, J. (2002). Wetland soils: genesis, hydrology, landscapes, and classification: CRC Press.

Weerasinhga, K. D. N., Chandrasiri, P.A.N., Rupasingha, C. \& Lexa, J.P. (1996). Climate, Soil and Water problems Encountered in Kirala Kele at the Down streams of Nilwala Ganga Scheme Paper presented at the Rehabilitation of the Nilwala Basin, Faculty of Engineering Tcehnology, The Open University of Sri Lanka. 